\title{
THE ARTISTIC SOCIAL AND ENVIRONMENTAL DIMENSIONS OF 3D
}

\section{STREET PAVEMENT ART}

\section{D SOKAK KALDIRIMININ SANATSAL SOSYAL VE ÇEVRESEL BOYUTLARI SANAT}

\author{
Mowafaq ALSAGGAR*, Monther AL-ATOUM** \\ * Associate Professor. Dr. Mowafaq Alsaggar. Yarmouk University; Faculty of Fine \\ Arts; Department of Plastic Art. Irbid. Jordan. Email: alsagar@yu.edu.jo ORCID 0000- \\ 0002-2854-2093 \\ ** Prof. Dr. Monther Al-Atoum. Yarmouk University; Faculty of Fine Arts; Department \\ of Plastic Art. Irbid. Jordan. Email: monzeral@ @otmail.com ORCID 0000-0002-1093- \\ 7345
}

\begin{abstract}
The subject of the study is based on the three-dimensional art of drawing on the ground, also called the art of three-dimensional pavement art, as it attracts audiences for its strangeness and its implementation with techniques based on visual deception, achieving the third dimension, as well as the comical or political sense that dominates these works. The study also aimed to reveal the artistic, aesthetic, social and cultural dimensions of the three-dimensional street pavement art, deriving its importance from the problem arising from the need to identify the artistic and social dimensions in the art of three-dimensional street pavement art within the limits of contemporary arts. The most prominent results of the study were that some artists' works, such as the artist Julian Beever, were affected by political trends that aimed to achieve the principle of the right to live for all of humanity. Artist Kurt Wenner also brought out the issue of genetically modified animals. Some of the artists' works also contributed to complementing a place environmentally, as when the artist Manfred Stader created a scene that appeared at the end of the world, but the artwork preserved the place so that it became a complement to the street. Also, in the artist Edgar Müller work in the zoo, so that the three-dimensional work became complementary to the place. Some artists also relied on their imagination from a historical perspective, such as the artist Leon Keer in forming the ancient Chinese soldiers in a giant three-dimensional work in the form of Lego. The goal was to spark scenes and reshape the event in Florida, which may contribute to attracting many people.
\end{abstract}

Keywords: Street pavement art, 3D floor art, street art, contemporary art.

Özet

Araştırmanın konusu, üç boyutlu kaldırım sanatı olarak da tanımlanan zeminde üç boyutlu çizim sanatına dayanmaktadır. Bu sanat tuhaflığa ve optik illüzyonlara dayalı tekniklerle üçüncü boyutunun yanı sıra bu çalışmalarda hakim olan komik ya da politik anlamın kitlelerin dikkatini çekmektedir. Ayrıca araştırma bu uygulamanın teknik yönleri ortaya çıkarmayı amaçlamaktadır.

M. ALSAGGAR, M. AL-ATOUM, THE ARTISTIC SOCIAL AND ENVIRONMENTAL DIMENSIONS OF 3D STREET PAVEMENT ART 


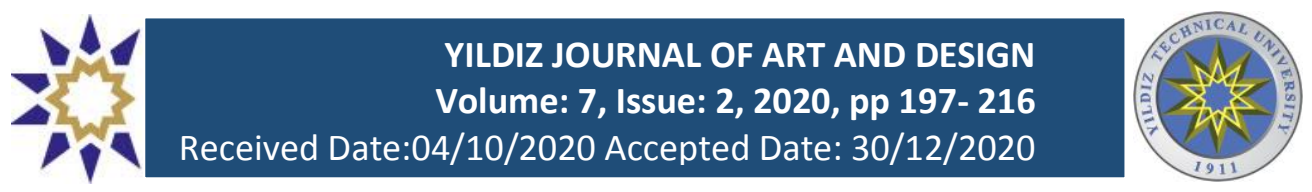

Çalışmada ayrıca üç boyutlu sokak kaplama sanatının sanatsal, estetik, sosyal ve kültürel boyutlarının ortaya çıkarılması amaçlanmaktadır. $\mathrm{Bu}$ da üç boyutlu sokak sanatı sanatında sanatsal ve sosyal boyutların çağdaş sanat sınırları içinde belirlenmesi ihtiyacından doğmaktadır. Çalışmanın en belirgin sonuçları, sanatçı Julian Beever gibi bazı sanatçıların eserlerinin, tüm insanlık için yaşama hakkı ilkesini gerçekleştirmeyi amaçlayan siyasi akımlardan etkilenmesidir. Sanatçı Kurt Wiener, genetiği değiştirilmiş hayvanlar konusunu da gündeme getirmiştir. Sanatçıların bazı çalışmaları da mekanın çevresel olarak tamamlanmasına katkıda bulunmuştur. Sanatçı Manfred Stader, dünyanın bir köşesinde ortaya çıkan bir sahne yarattığında olduğu gibi, sanat eseri yeri korunarak sokağın tamamlayıcısı haline gelmiştir. Sanatçı Edgar Müller'in hayvanat bahçesindeki çalışmasında, üç boyutlu eser mekanı tamamlamaktadır. Eski Çin askerlerini Lego şeklinde kocaman bir üç boyutlu çalışmaya dönüştüren sanatçı Leon Kerr gibi bazı sanatçılar, tarihsel bir perspektiften de ilham almaktadır. Burada da amaç, sahneleri heyecanlandırmak ve çok sayıda insanı çekebilecek olan Florida'daki etkinliği yeniden yapmaktır.

Anahtar kelimeler: sokak kaplama sanatı, Üç boyutlu yer sanatı, sokak sanatı, çağdaş sanat.

\section{Introduction}

In the past few years, the expression of three-dimensional drawing has appeared, wherein the artist uses a third dimension in addition to the dimensions of length and width in the drawing, which is dimensioned $\mathrm{z}$ or (height). Three-dimensional artists work to deceive the eyes, so that the drawing appears as a real body with its length, width, and height, and is not perceived. It is just a drawing on a wall, paper, or the street, except when you approach and feel it. 3D Street Drawing, also known as 3D City Drawing or 3D Street Art, allows viewers to experience the immersive feeling of a wonderful world. The principle of 3D drawing is based on the inverse application of perspective, called the principle of inverse perspective. It is a drawing technique in which the drawn object passes through a specific viewpoint and displays the image of the image holder in the reverse direction according to the rules for photographing the visual, and it requires a great perspective. An artist needs to understand the principle of perspective before he/she can produce his/her artwork.

Three-dimensional drawings are present on roads, on the ground and on the walls. They are considered some of the most beautiful forms of art in the world, according to the views of observers, due to the elegant touches they carry and a distinctive real

\section{ALSAGGAR, M. AL-ATOUM, THE ARTISTIC SOCIAL AND} ENVIRONMENTAL DIMENSIONS OF 3D STREET PAVEMENT ART 
dimension. Three-dimensional drawing is often the drawing of real models in nature, with its three dimensions shown. Three-dimensional drawing has several methods of drawing, both famous and less well-known, and the most famous of them is the 45-degree drawing method. There is also the 30-degree drawing method, and each of them has its own characteristics that distinguish it from others.

Street sidewalk art is the performance art of presenting artistic designs in the outdoors such as streets, sidewalks, and town squares, with impermanent and semipermanent materials such as chalk. The origins of modern street painting can be traced back to Britain, as sidewalk artists were found throughout the United Kingdom, and by 1890 it was estimated that more than 500 artists lived alone in London on sidewalk art (Fig. 1). The British term for a pavement artist is "painting on the road" and this term derives from the style of writing and often from the copper chip that usually accompanied the work of pavement artists. The term painting on the road is more common since the 1700s, but it is mentioned in the Shakespearean vernacular dating back to about 1500 (Network, 2017) .

\subsection{The art of 3D drawing}

This visual art is concerned with three-dimensional designs that give the recipient an optical illusion at the moment of observation. Considering that the three-dimensional drawing has several methods of implementation, some of them are known and others are unknown. The well-known method is the method of drawing at a 45-degree angle, and there is also the method of drawing at a 30-degree angle; each of them has its own characteristics and style that distinguish it from others (Schwarzenbach, 2015). The art of drawing on the ground in contemporary formation is considered a global phenomenon since its prosperity in the early years of 2008 when self-expression became easier and faster for everyone to receive these works. After 2011 three-dimensional street art became loaded with connotations of an intellectual, societal, and political nature most of the time; thus, many artworks were produced. In America and Europe, which relied on the techniques of drawing on the ground, it also revealed the intellectual, political,

M. ALSAGGAR, M. AL-ATOUM, THE ARTISTIC SOCIAL AND ENVIRONMENTAL DIMENSIONS OF 3D STREET PAVEMENT ART 


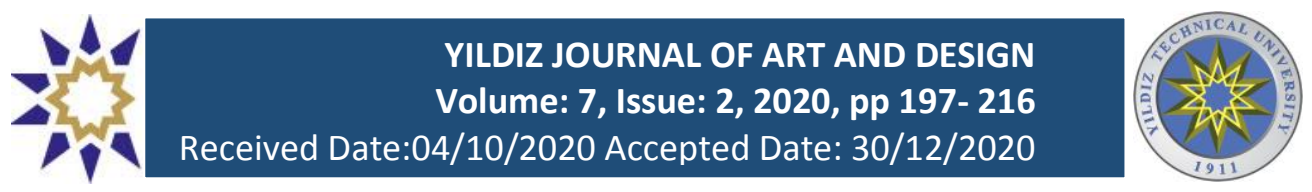

cultural, and social aspects. As we notice that it is possible to create a visual perspective in the artwork, which makes the visual scenes that we see appear as if their shape and size change based on the angle from which it is viewed, when the artist reconfigures things in art by one of the methods or theories of illusion, the most important of which is the socalled reflection. This refers to the lights on soft objects and their change of color according to the angle of incidence. In addition to the so-called (refraction), which creates errors in the image when there is a defect in the vision system down to (polarization) as a piece of the axially moving crystal that suggests light and darkness at the moment of its movement and also what is called (dispersion), as it is obtained in the prism and the light decays into seven colors (Edelson, 2008) .

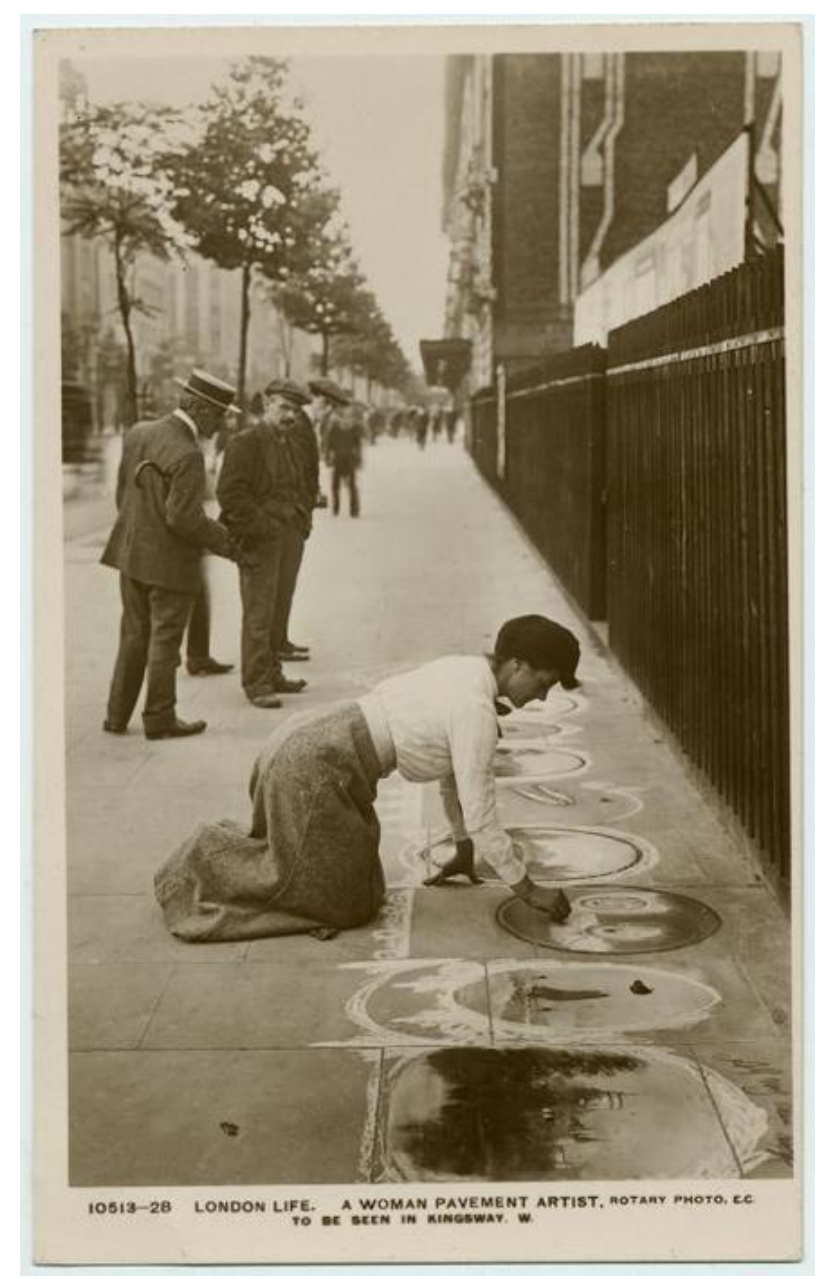

Fig 1. Woman street painter in London, c1900; from NYPL Digital Collections

M. ALSAGGAR, M. AL-ATOUM, THE ARTISTIC SOCIAL AND ENVIRONMENTAL DIMENSIONS OF 3D STREET PAVEMENT ART 200 


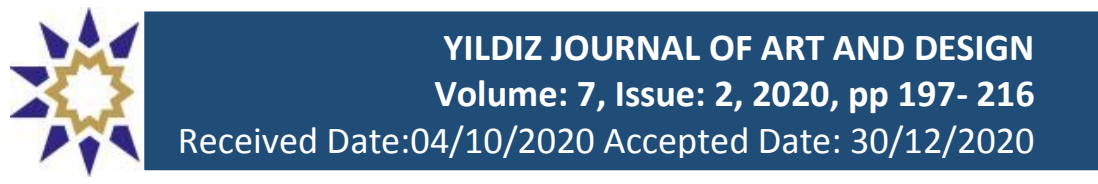

YILDIZ JOURNAL OF ART AND DESIGN

Volume: 7, Issue: 2, 2020, pp 197- 216

Received Date:04/10/2020 Accepted Date: 30/12/2020

Tiffany Renée Conklin (2012) conducted a study titled Street Art, Ideology, and Public Space. The study aimed to clarify the concept of the city, which plays a central role in the practices of a new generation of artists whose paintings represent the city. She also made clear that street art is a complex social issue. For decades, its existence has sparked intense debate among residents of modern cities. Some consider street art to be a natural expression that exercises a collective right in the city, others view it as a disturbing attack on a clean and orderly society. The study focused on the different forms of street art from the perspective of an urban audience. Conklin's overall goal was to increase understanding of how people interact and respond to street art. Qualitative and quantitative data were collected through direct participant observations of street art installations and 139 surveys conducted with residents of Portland, Oregon. Respondents made a distinction between street art forms. They generally prefer compositions and masterpieces to labels and stickers (Conklin, 2012).

Christina Marie Gleaton's (2012) study, Power to the People: Street Art as an Agency for Change, aimed to clarify the phenomenon of the simple sign that has developed into a global phenomenon that conveys to us an uncensored message of vocation, humanity, and freedom. Street art acts as a reflection of our very existence, and it continues to speak to us in ways that we all seem to understand. Forcing us to pay attention, displays of artistic expression and vandalism shout for us to pause, look and think about our environments and to give effective meaning to what we see (Gleaton, 2012) .

Katie Smith (2014) conducted a study entitled Street Art: An Analysis under U.S. Intellectual Property Law and Intellectual Property's Negative Space Theory, which aimed to expose street art, in its original and most pure form, as a work of art created without a license, usually illegally, whether on private or public property. Until recently, street art was considered a social nuisance and was practically illegal around the world, but it is now slowly becoming a "hot commodity" that attracts the attention of the press and social media. In recent years, local communities have increasingly begun to value street art in their neighborhood and the art world has taken over the street art trend. As a M. ALSAGGAR, M. AL-ATOUM, THE ARTISTIC SOCIAL AND ENVIRONMENTAL DIMENSIONS OF 3D STREET PAVEMENT ART 201 
result, street art is copied and reprinted on clothing, posters, and commercial materials, displayed, and sold in auction houses and galleries. Cities like Bristol, Bethlehem and Taichung are embracing street art by offering guided tours to showcase famous street art. Street art - no longer considered just a social nuisance as it once was - is now the "next big thing" in the world of art and the market. Street art is also developing into a commodity. Of course, the questions are: Who owns street art, and should intellectual property law protect street art from unauthorized copying, removal, sale, or destruction? (Smith, 2013).

\section{Study Plan}

\subsection{Research Statement:}

The problem of the study is based on the three-dimensional art of drawing on the ground, and it is also called three-dimensional pavement art, and it attracts numbers of audiences for its strangeness and its implementation with techniques based on visual deception, achieving the third dimension, as well as the comical or political sense that dominates these works. As those artworks attract the public, they also attracted large numbers of plastic artists, who found their inspiration on the street pavements. Their arts were inspired by the interests and needs of people, so that these works appeared as one of the street's environmental components. The city squares and streets also became a canvas for many artists. Street art has become a social and environmental issue, and its existence has sparked controversy among modern urban residents. The study problem reveals the need to research this topic and study its technical, social, and environmental dimensions. The study's main question states: What are the artistic, aesthetic, social and cultural dimensions of the three-dimensional street art?

\subsection{The purpose of the study and its importance:}

The current study aims to reveal the artistic, aesthetic, social and cultural dimensions of the three-dimensional street pavement art, deriving the importance of its problem arising from the need to identify the artistic and social dimensions in three-dimensional 


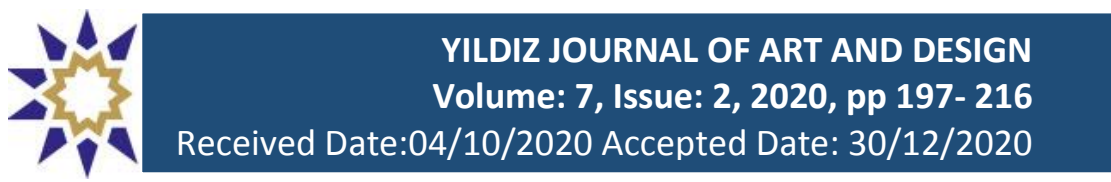

YILDIZ JOURNAL OF ART AND DESIGN

Volume: 7, Issue: 2, 2020, pp 197- 216

Received Date:04/10/2020 Accepted Date: 30/12/2020

street pavement art within the limits of contemporary arts. Addressing this problem meets the following needs:

1. The need of art students and those interested in the aesthetics of contemporary art and what the street art embodies.

2. Opening broad knowledge and philosophical horizons in the study of artistic and societal problems in contemporary arts.

\subsection{The limitations of the study:}

The current study is based on objective boundaries that were limited to analyzing illustrated models of some of the works of drawing executed on the ground and found in some foreign sources and some encyclopedic books as well as on websites, and temporal boundaries that the researchers confined from the period 2005-2020 and with spatial limits represented by artists from Europe and America.

\subsection{Study methodology and procedures:}

-Study population: Although the researchers have seen many pictures of the art of three-dimensional drawing on the ground in contemporary international art, which are defined in the period from 2005-2020, he was unable to statistically restrict the community to numerical abundance, and accordingly, the researchers benefited from only some of the documented products obtained from some sources. The foreign samples that the researchers summarized, as well as some informational network sites and covering the research, amounted to about 60 models, which served as an exploratory sample.

- Study Model: Illustrated models of the art of drawing on the ground were intentionally chosen and there are (5) models, with various techniques and places, as it has topped the sites of three-dimensional art, because of the very high skill and technique it contains and the themes and ideas that celebrate the novelty and originality give the other aesthetics in the illusions.

M. ALSAGGAR, M. AL-ATOUM, THE ARTISTIC SOCIAL AND ENVIRONMENTAL DIMENSIONS OF 3D STREET PAVEMENT ART 203 


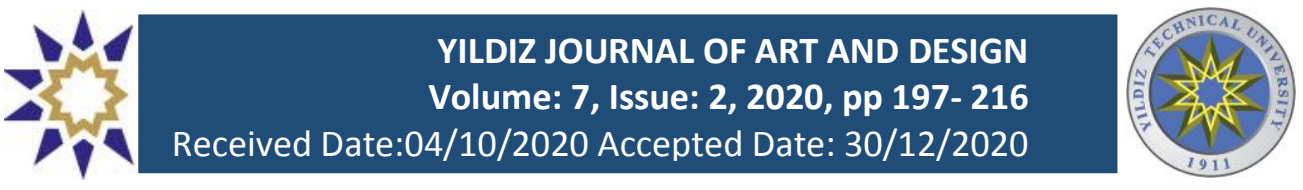

- The study tool: Through the detection of the tools of drawing on the ground and its apparent techniques, the aesthetic, cognitive and technical indicators presented in the theoretical framework was adopted, which contribute to enriching the analysis and directing it scientifically to serve as an applied tool in the analysis.

- Research methodology: The researchers adopted a descriptive and analytical approach in analyzing the current research sample, in order to identify aesthetic, societal and environmental approaches in the art of drawing on the ground, according to several axes, the first of which is the visual description, and then an analysis of the elements of formation and techniques of demonstration down to visual aesthetics.

\section{Model analysis}

\subsection{Kurt Wenner}

Kurt Wenner used his inexhaustible talent to promote both good causes and important political issues. One such action was Greenpeace against the production of genetically modified organisms, or genetically modified crops as they are often known. This wide circular piece also contained one million signatures on a petition against GMOs and was the first petition to be considered a "citizen's initiative" (Greenpeace, 2020). Wiener's work uses his suspense style to depict crops and livestock, as well as figures that are speaking out against GMO crops. An important work for Wenner, it shows how art can be used to strengthen a cause (Fig. 2). The artist nominated in the subject of many meanings for understanding and interpretation through his presentation of a composition that accepts interpretation, which gives the viewer the ability to transmit expressive energies of a beautiful character, within the circle of communication; communication that expands the spaces of participation as an expression of the concept of bridging the gaps between art and society (Wenner, 2020).

M. ALSAGGAR, M. AL-ATOUM, THE ARTISTIC SOCIAL AND ENVIRONMENTAL DIMENSIONS OF 3D STREET PAVEMENT ART 204 

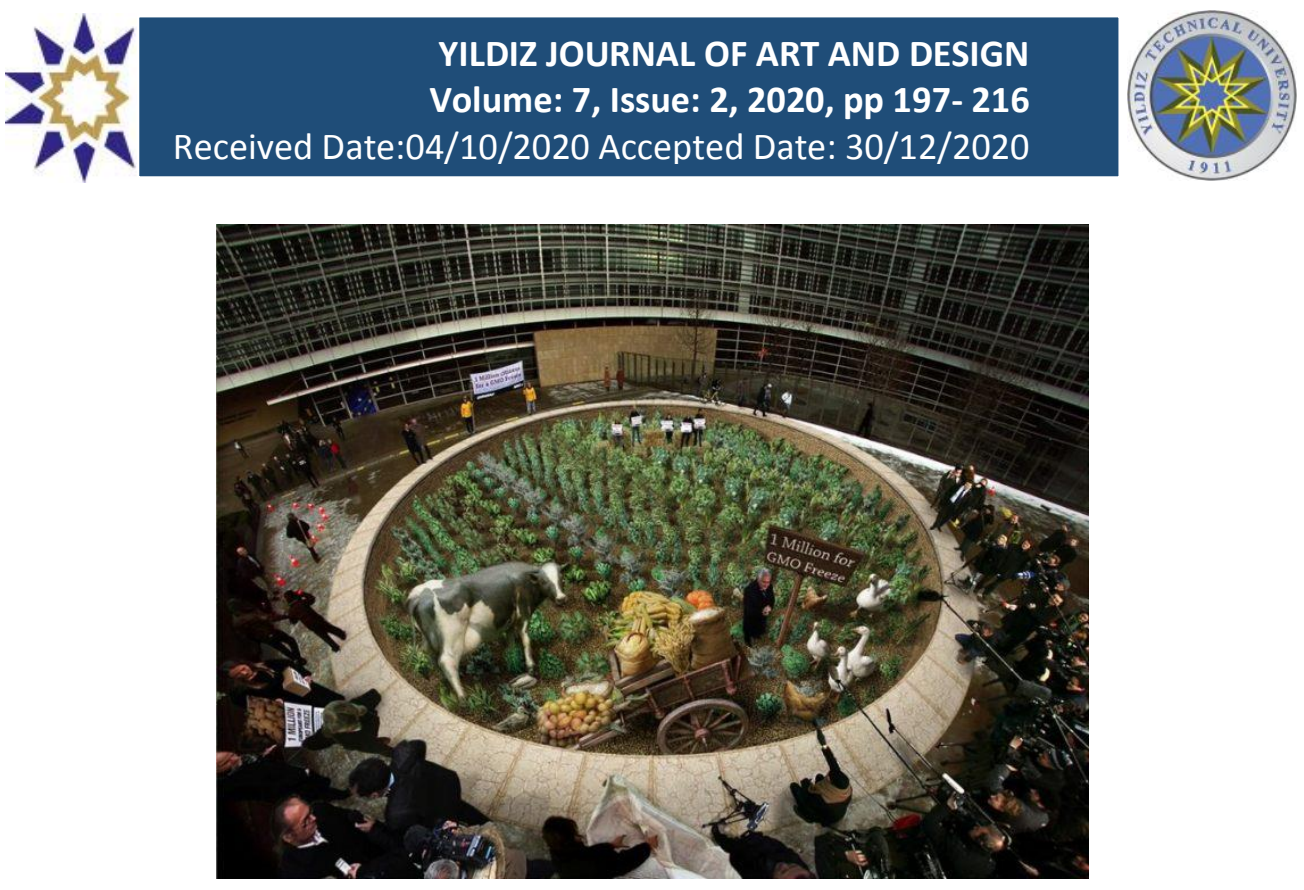

Fig 2. Greenpeace - Million Signatures. Brussels, Belgium. Kurt Wenner 2010. Workload: a 4,100 square foot

The artist, in his artistic style, and in his demarcation of the third dimension in the scene, has turned towards a narrative that opened horizons with his cultural and visual surroundings and revealed skills and techniques that go beyond reality to achieve the aesthetic dimension. The artist possessed an epistemological and cultural depth in the Western heritage, forming an act of passive kinetic performance that gave the work a cognitive aesthetic through the embodiment of a three-dimensional drawing influenced by the idea of recreating scenes of unstable nature and its visual installation on the surface of the earth, but with contemporary visions (Kuehni, 2008).

Kurt Wenner succeeded in intensifying the alternating spiral movements (the vortex) to demonstrate its existence, thus determining for us the pleasure and quality in proposition, implementation, selection, assembly, and reformulation that gives the general composition of the scene a technical, objective, and aesthetic unity. The artwork becomes a visual invitation to the existence of a real scene on the ground that allowed the viewer to communicate with him visually and emotionally, which takes place through the illusory act of receiving in a three-dimensional drawing on the ground. In other words, the aesthetic values in the panoramic scene of the artist are varied according to the diversity of its various techniques (Wenner, 2011).

M. ALSAGGAR, M. AL-ATOUM, THE ARTISTIC SOCIAL AND ENVIRONMENTAL DIMENSIONS OF 3D STREET PAVEMENT ART 205 


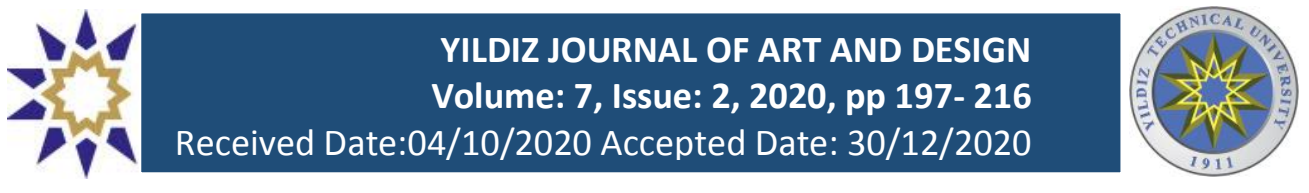

\subsection{Julian Beever}

Julian Beever is a sidewalk chalk artist who is an expert in art, perspective, creativity, and performance. The artist's work is more than just traditional flat graphics, the works he creates are uniquely 3D visual graphics. They are drawn in perspective and distorted so that the subject can only be properly viewed from a particular perspective. For those standing in the right place, his chalk drawings invite direct entry into the scene or, in the case of the artist's famous pool on High Street, dive straight into the water. Pavement Chalk Artist includes an impressive set of Beever's most blurry drawings. Each one is accompanied by a description of the techniques he used and the challenges he overcame. These images record the development of his extraordinary skill and understanding of perspective. Readers can see how his art develops and matures as he undertakes commissioned works and a wealth of original and innovative themes in locations around the world. The images tell the story, giving readers an understanding of the principles of this $3 \mathrm{D}$ art form and the pleasure of sharing scenes enjoyed by passersby before these unique works disappear forever (Beever, 2012).

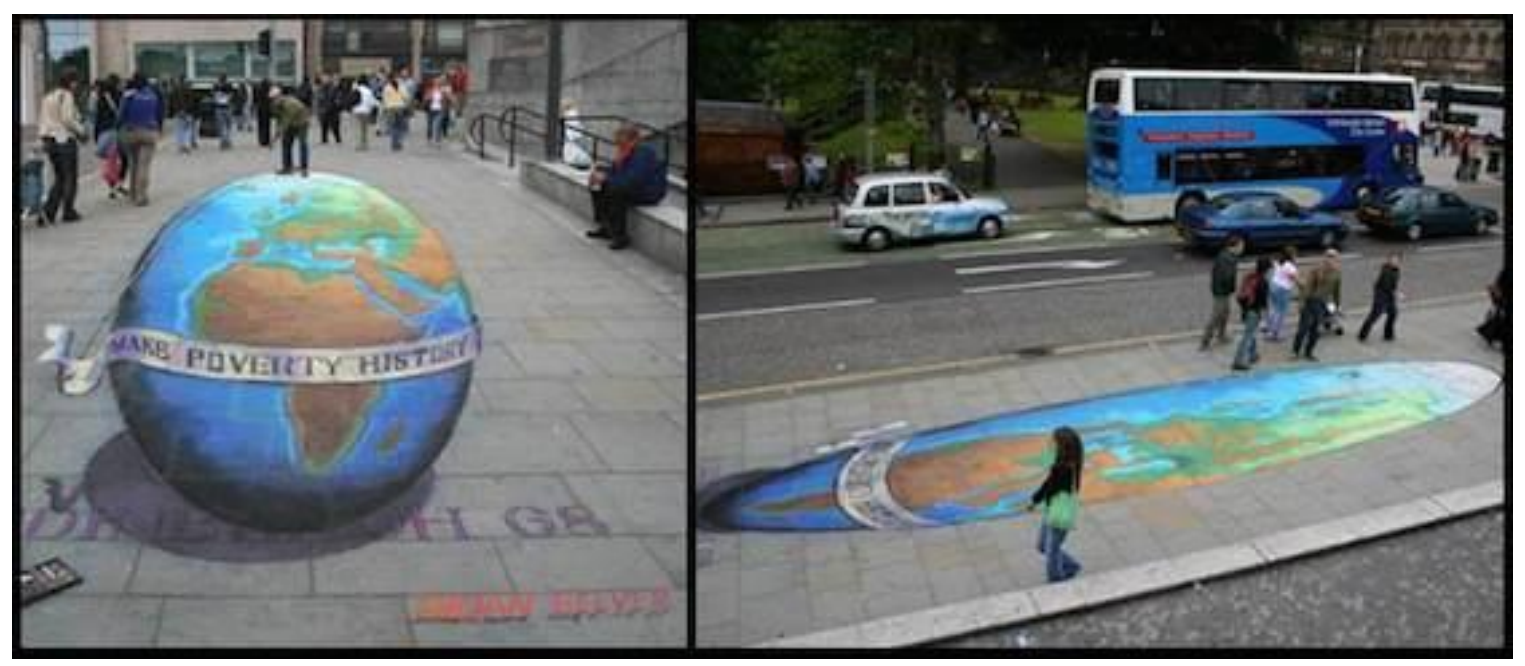

Fig 3. The 'make Poverty History'. Edinburgh. Julian Beever. 2005

The artist drew the theme "Make poverty from the past" at the request of Live 8 (a group of more than a thousand musicians who performed concerts before each meeting of the Group of Eight in several different capitals in 2005) (Fig. 3). The musicians M. ALSAGGAR, M. AL-ATOUM, THE ARTISTIC SOCIAL AND ENVIRONMENTAL DIMENSIONS OF 3D STREET PAVEMENT ART 206 


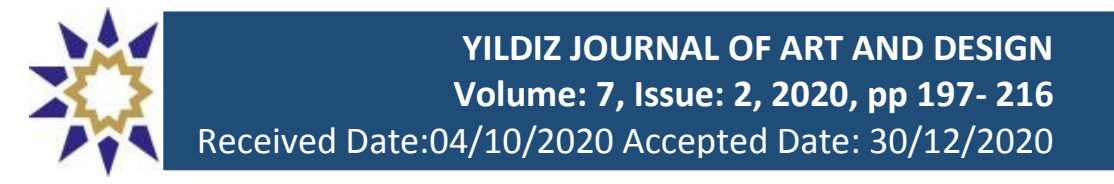

performed in order to put pressure on the Group of Eight that were meeting in the city of Edinburgh and Australian cities. Make poverty history is the name of organizations in several countries that focus on issues related to MDG 8 such as aid, trade, and justice. They generally form a coalition of aid and development agencies that work together to raise awareness of global poverty and bring about government policy changes. The movement is present in Australia, Canada, Denmark, Finland, New Zealand, Nigeria, Norway, Romania, South Africa, Ireland, the United Arab Emirates, the United States of America, and the United Kingdom. Their various national campaigns are part of the Global Call to Action Against Poverty campaign (Sherman, 2018).

\subsection{Edgar Müller}

On the 30th anniversary of the International Street Painting Festival in Geldern, Edgar Müller painted a large, three-dimensional portrait again. He created a scene appearing at the end of the world that invited the viewer to move along with the image. Müller turned the street into a river shaped by the collapse of the earth. In his 3D painting of a street called Love Proust, a street in Geldern, Germany, appears to have been demolished by a volcano and an earthquake (Fig. 5). The street splits in the middle to become a turbulent river, the rocks glowing in the cracks a reddish-brown color like lava. It looks very realistic, as if the city has just suffered a doomsday disaster in a Hollywood movie. On the three-dimensional plate called "The Cleft of the Earth," a huge crack appears on the ground, and a pedestrian is walking precariously on the only remaining "island" in the middle of the gap, looking as if he is falling into it (Leu-Merveille, 2019).

M. ALSAGGAR, M. AL-ATOUM, THE ARTISTIC SOCIAL AND ENVIRONMENTAL DIMENSIONS OF 3D STREET PAVEMENT ART 207 

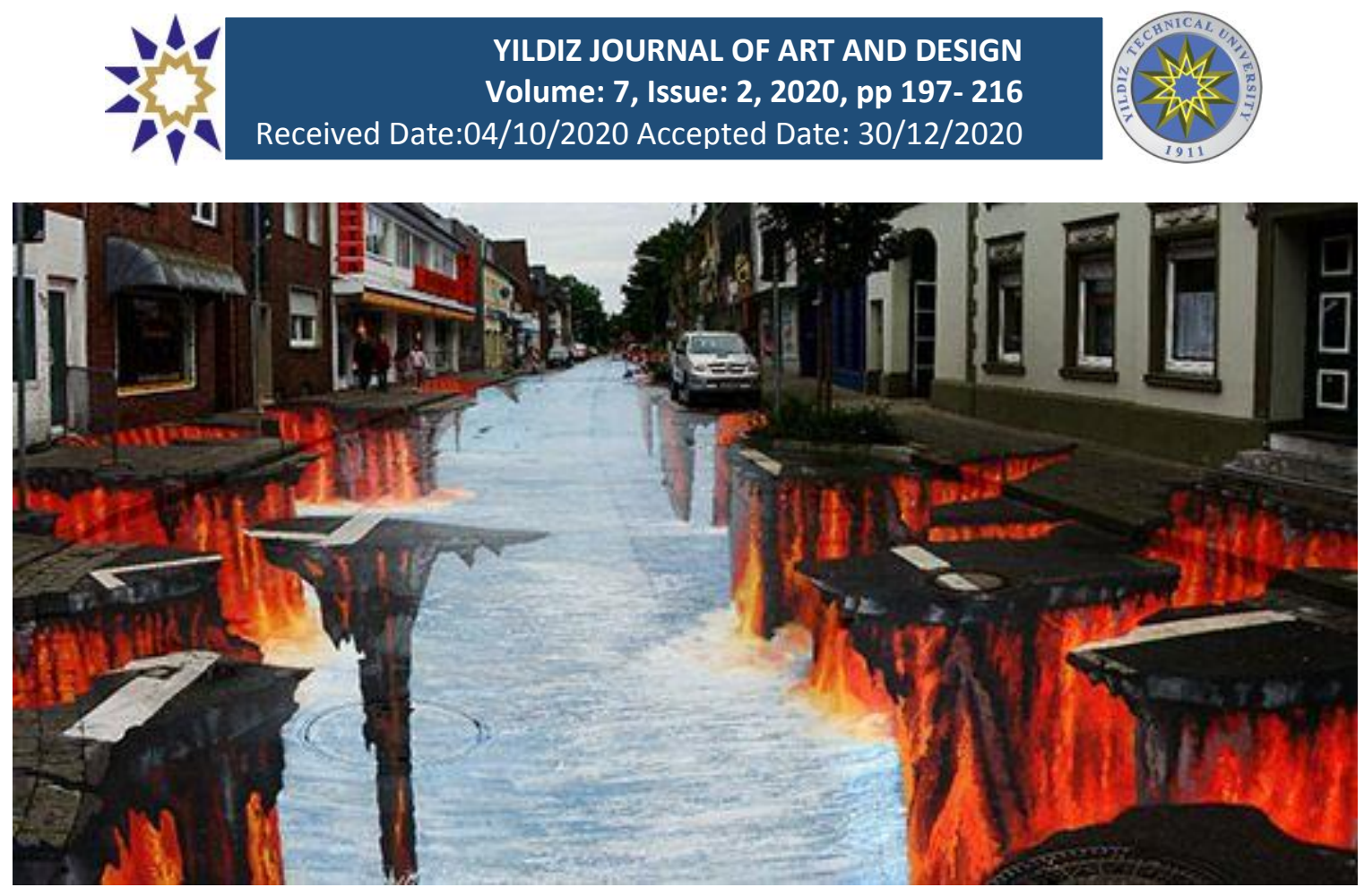

Fig 4. Lava BurstLa. Geldern Germany. Edgar Müller. 2008

We notice the presence of a wide rectangular area, with a large scene of a deep valley. A large waterfall pours from the top of the rocky mountain into a long, blue river. Many colorful words swim in the water, as well as a spiral formation in the center of the scene surrounded by many irregularly shaped blocks. Two white stones are scattered about as if they were living creatures and may suggest that they are scattered snow masses. The valley is surrounded by lava.

Edgar Müller was interested in drawing a large panoramic scene on the ground. He used a wide area with minute details to convey an optical illusion. To viewers it appears as if we are in front of a big event. Watching him complete his work brings pleasure in anticipation. We notice that the imagination that the artist used in installing the parts of his pictorial scene made the visuals in the photographic scene appear to move. The error in our perception of the scene produces a visual illusion that seems real even though it is a trick of sight. Our sensations clash with the scene of the drawing. We find that they give us information about the stimuli and changes that happen to the viewer psychologically and biologically. The event is experienced by our five senses. We feel

M. ALSAGGAR, M. AL-ATOUM, THE ARTISTIC SOCIAL AND ENVIRONMENTAL DIMENSIONS OF 3D STREET PAVEMENT ART 208 
beauty, fear, pleasure, and the yearning for participation, movement, attention, and imagination so that we become part of the artwork (Leu-Merveille, 2019).

In Müller's scene we find he has emphasized Aristotelian harmony between the visual elements of the composition, which represent the basis of beauty and aesthetics. This contributes to the third dimensional visuals (depth). Our selective processes interpret what we see, and our perception of the scene combines with an overlap of sensations. The viewer, with limited knowledge of the process, sees the overlapping of the vertical and transverse axis and this results in a misinterpretation of the vision. The subject and style depend on the artist's ability to explore the potential of the materials used to present the idea. The eye is directed toward beauty and away from monotony and the reality of the surroundings. The viewer's involvement in the artistic event is represented by the three-dimensional drawing. The panoramic view gives us a visual to illuminate the presence of a three-dimensional perspective in the drawing on the ground.

\section{4 . Leon Keer}

Leon Keer is a Dutch surrealist pop artist who created canvas and artwork on the streets all over the world. Leon Kerr is a pioneering artist in creating street art by likeness. Figure 5 shows the artwork that was produced by a group of Dutch street artists, as part of the Sarasota Chalk Festival in Florida. Artist Leon Kerr, who led the project, said it was inspired by the avatar of the Chinese Terracotta Army of 8,000 soldiers that was first discovered in 1974 and is now one of the biggest tourist attractions in China. This artwork was designed Leon Kerr and executed by Leon Kerr, Peter Westernerck, Robin Bonsia and Remco Van Shayk. The artwork was produced by this group of Dutch street artists as part of the Sarasota Chalk Festival in Florida (PARSONS, 2011).

M. ALSAGGAR, M. AL-ATOUM, THE ARTISTIC SOCIAL AND ENVIRONMENTAL DIMENSIONS OF 3D STREET PAVEMENT ART 209 

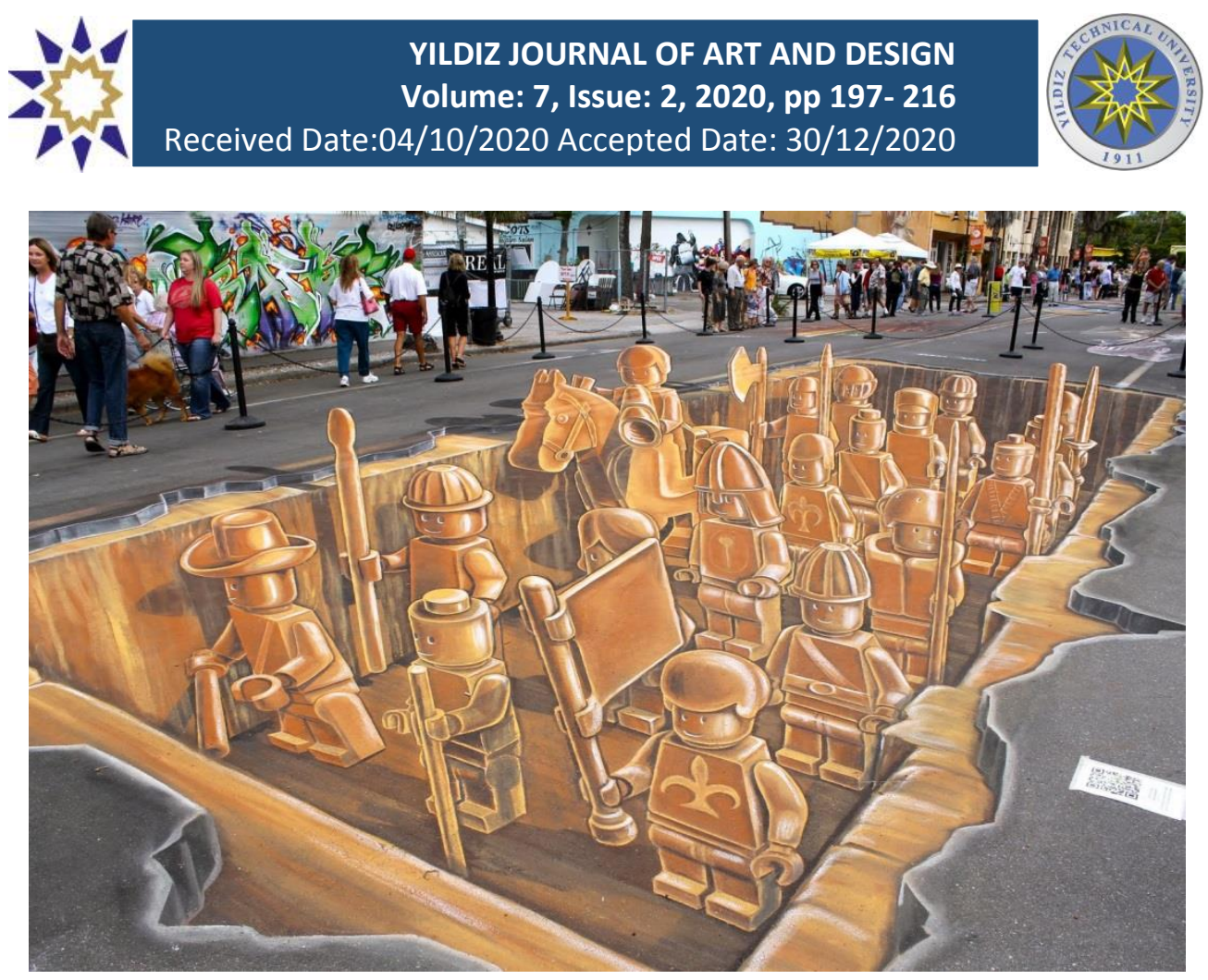

Fig 5. 3D Lego terracotta army. Chalk festival Sarasota, Florida. Leon Keer. 2011

As noted above, this 3D street artwork was inspired by the terracotta army of Qin Shi Huang (Fig. 6), the first emperor of China, and executed in a contemporary style. We notice the characters represented by a girl with clay soldiers ready for war. The work may not have the historical significance or sheer scale of its real-life counterparts, but this portrait of Chinese clay warriors is still an impressive sight. Street art has brought the famous Chinese Terracotta Army back to life - in the form of Lego figures. This kidfriendly $3 \mathrm{D}$ version of this life-size Terracotta Corps was drawn with chalk on a flat street, giving the impression that the Lego figures could be seen halfway (Keer, 2020).

Painting on the ground contributes to linking art with general social life, in proportion to the theater of the event. Where the general composition of the visual scene grants the effectiveness of balance and coordination between the parts, on the one hand, and between the angle of view and the scene on the other hand, to intensify the aesthetics of visual illusion in the art of drawing on the ground, to involve the recipient in the creative process. The graphic scene we find was executed with high-quality technique and skill at a 45-degree angle, to attract the attention of the recipient and achieve the third dimension.

M. ALSAGGAR, M. AL-ATOUM, THE ARTISTIC SOCIAL AND ENVIRONMENTAL DIMENSIONS OF 3D STREET PAVEMENT ART 210 


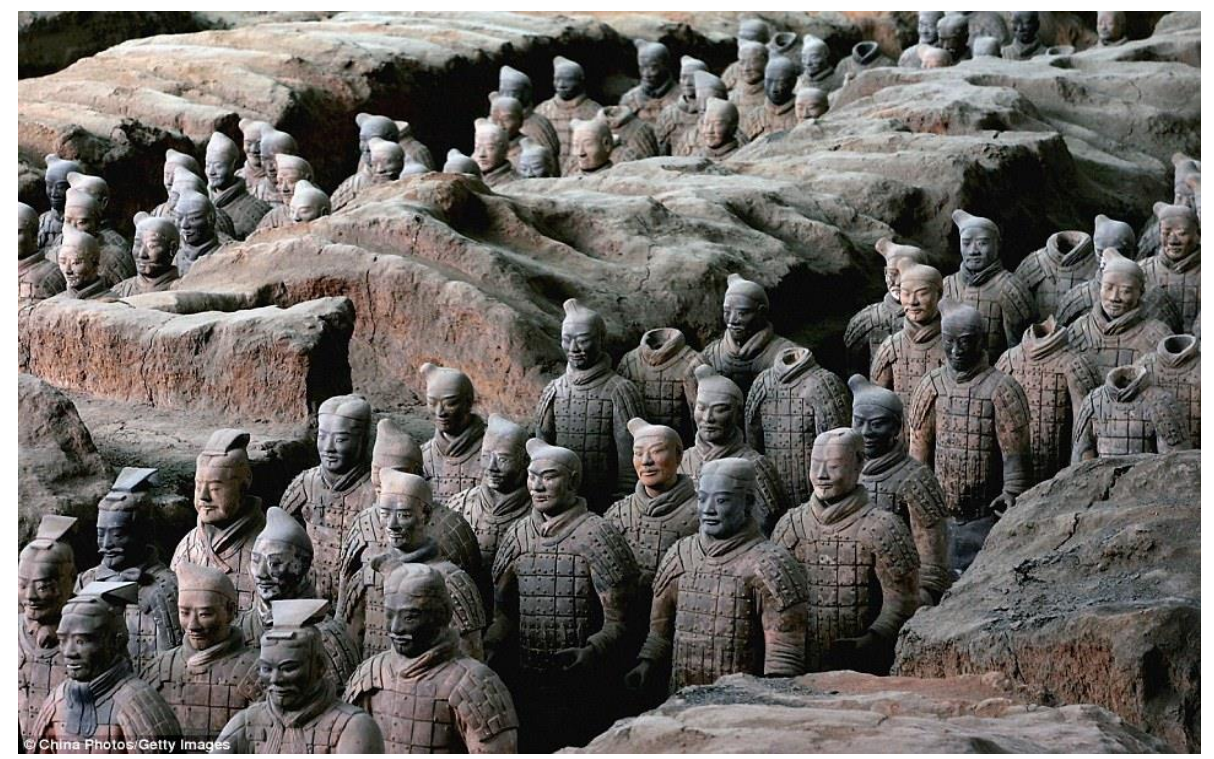

Fig 6. Real life: The real version of the Terracotta Army was first discovered in 1974 and it totals thousands of soldiers made for China's first emperor.

\subsection{Manfred Stader}

Manfred Stader began painting on the street and on the pavement during his art studies in the early 1980s. In 1985 he became one of the few master street painters, earning the title of "Maestro Madonnaro", a title awarded in the largest international street painting competition in Grazie di Curtatone in Italy (Staff, 2011). Figure 7 shows artwork that was produced by Manfred Stader. In this scene, the artist painted a rectangular area with several sweeping waterfalls that descend from among large rocks from the top of the surface towards the inside of the open space. We also notice the presence of a prominent eagle in the center of gravity of the painting, as well as many other rocks distributed in the middle. The artist adopted the principles of threedimensional drawing in this panoramic scene on the ground, which made him interested in the idea in a theatrical scene that achieves astonishment for the audience during their passage or his enjoyable participation in displaying the imaginary event (waterfalls) through the act of illusion. The clash with the general scene drawn on the ground gave the interlocutor's imagination the ability to communicate with the event of the subject and the geographical, intellectual, technical, and aesthetic environment. This contributed to M. ALSAGGAR, M. AL-ATOUM, THE ARTISTIC SOCIAL AND ENVIRONMENTAL DIMENSIONS OF 3D STREET PAVEMENT ART 


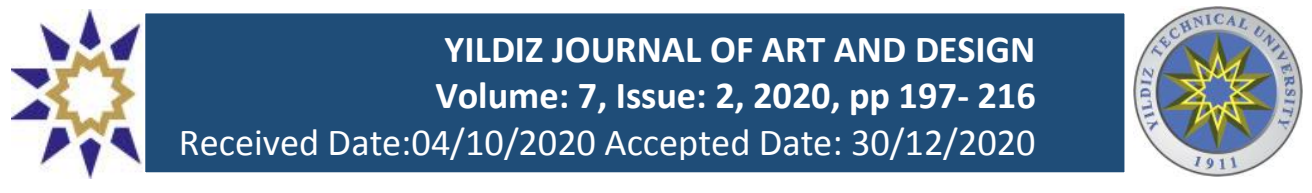

achieving aesthetic values of a conceptual nature, depicting the scene in a realistic and lived state that causes the mind of the recipient to enter directly into the event, the moment the photograph was taken from A specific angle through which the receiver is attached to the scene to make the other illusion that it is part of the spectacle (SEJACKSON907, 2017).

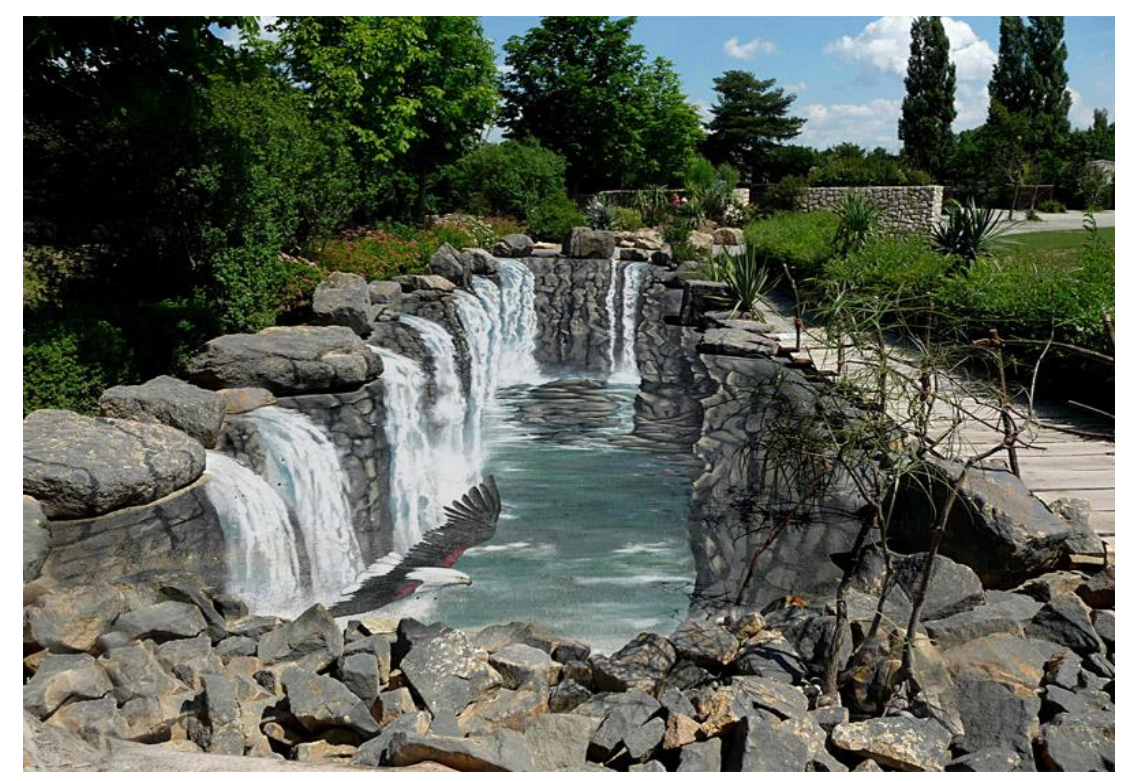

Fig 7. 3-D STREET ART Dvůr Králové Waterfall. Czech the zoo of Dvur Kralove. Manfred Stader. 2013. Acrylics on asphalt - 25 x 6 meters.

The artist (Stader) tried to paint the event in an environment that suited the origin of the subject to build a specific mental, intellectual, and aesthetic climate, using the aesthetics of the three-dimensional perspective and open space. He also used ready-made shapes, a group of rocks at the moment of photography, to complete the pleasure of the visual illusion. Between the part (the rocks) and the whole (the drawn scene), within the boundaries of the workspaces, there can be a more sensitive depth and influence in the mind of the recipient that is directly proportional to the Gestalt law. This means that the artist placed the recipient at the center of gravity of the work with a theatrical undertone by borrowing an area of land from the zoo in the Czech Republic, using the floor in drawing rocks and waterfalls in a realistic manner, investigating the third depth, which

M. ALSAGGAR, M. AL-ATOUM, THE ARTISTIC SOCIAL AND ENVIRONMENTAL DIMENSIONS OF 3D STREET PAVEMENT ART 


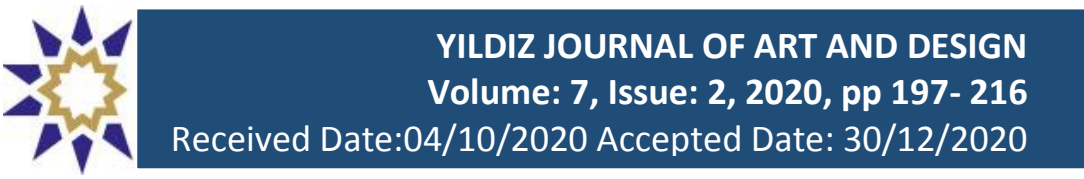

YILDIZ JOURNAL OF ART AND DESIGN

Volume: 7, Issue: 2, 2020, pp 197- 216

Received Date:04/10/2020 Accepted Date: 30/12/2020

deludes from a specific angle the anthropomorphism of the movement of the waterfalls, their speed and features close to reality, giving the recipient aesthetics in visual illusion.

\section{The results}

The results of the study related to the main study question, "What are the artistic, aesthetic, social and cultural dimensions of the three-dimensional street art?":

1. The dependence of the three-dimensional drawing artists on the ground to represent and dramatize the event in an environment alien to it, which gives the other (the recipient) the pleasure of surprise, and novelty in receiving and interacting and contributing to the production and marketing of the work culturally, intellectually, and visually, as in all sample models.

2. Three-dimensional street pavement drawings depended on the aesthetics of the social and environmental aesthetic metaphor. A type of communication and juxtaposition was established between the artist, the artwork, and the recipient.

3. The artist's interest in the issue of drawing the attention of the receiving mind and its excitement by intensifying the aesthetics of the visual illusion within a 45-degree angle, to contribute to the neglect of other stimuli.

4. Some of the works of artists, such as the artist Julian Beever, were affected by political trends that aimed to realize the principle of the right to life for all of humanity. The artist Kurt Wenner also brought out the issue of genetically modified animals.

5. Also, some of the artists' works were ecologically important, as it appeared when the artist Edgar Mueller created a scene that appears at the end of the world, but the artwork preserved the place so that it became a complement to the street. In the artist' Manfred Stader work in the zoo, so that the three-dimensional work became complementary to the place.

6. Artist Leon Keer relied on his imagination from a historical perspective in shaping ancient Chinese soldiers into a giant 3D Lego-shaped work. So that the goal was to

M. ALSAGGAR, M. AL-ATOUM, THE ARTISTIC SOCIAL AND ENVIRONMENTAL DIMENSIONS OF 3D STREET PAVEMENT ART 
stimulate the scenes and reshape the event in Florida, which may contribute to attracting more people.

\subsection{Discussion}

Three-dimensional street pavement artists tried to attract the viewer, not only aesthetically, but also in deepening and consolidating important human issues such as social and environmental issues. The artists tried to make their work complementary to the issues they emphasized in their work. The aesthetic work also contributed to engaging the recipient in the creative process at the moment of engagement with the text, as the scenes of drawing on the ground possessed aesthetic, social and environmental values in a three-dimensional form to create scenes of a panoramic character, celebrating the details that produce an interconnected relationship between the part and the whole, in favor of the most present depth in contemporary art . Artists of drawing on the ground emphasized the concept of Aristotelian harmony between the elements of the work and the recipient, to contribute to attracting the largest possible number of viewers, as the art of drawing on the ground emphasized the importance of influence and its aesthetics, in reconfiguring the geography of public places through the act of drawing and counting it among the fine arts common in the world. This is required by the recipients, as it gives pleasure, participation, communication, and connection to the other.

Land arts did not rely on the issue of informing (media) about information as much as it was concerned with stimulating attention in favor of visual and mental communication. Postmodern arts were concerned with showing the aesthetics of technology and performance in panoramic production. Postmodern arts, in particular, earth arts, relied on the principle of engaging the recipient in the process of visual illusion and drama of the event, and counted as places for strolling and enjoying the aesthetics of 3D formations.

M. ALSAGGAR, M. AL-ATOUM, THE ARTISTIC SOCIAL AND ENVIRONMENTAL DIMENSIONS OF 3D STREET PAVEMENT ART 214 


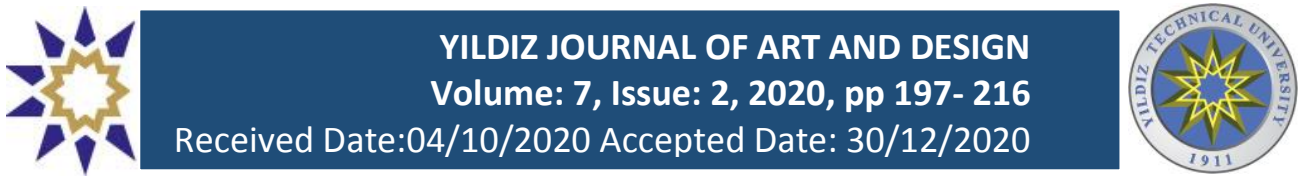

\section{References}

Beever, J. (2012). Pavement Chalk Artist: The Three-dimensional Drawings of Julian Beever. North American: Firefly Books.

Conklin, T. R. (2012). Street Art, Ideology, and Public Space. Portland : Portland State University.

Edelson, B. (2008). Street Art NOIR. Street Art Noir.

Gleaton, K. M. (2012). Power to the People: Street Art as an Agency for Change.

Minnesota: The University of Minnesota.

Greenpeace. (2020, 9 7). Kurt Wenner Pavement Art Gallery 1. Retrieved from

http://kurtwenner.com/galleries/pavement/pavement_1/pages/StreetPaintingGallery1. 003.htm

Keer, L. (2020). Leon Keer - Distortion. Tielt: Lannoo N. V., Uitgeverij.

Kuehni, R. G. (2008). Color Vision and Technology. North Carolina: AATCC.

Leu-Merveille, S. L. (2019). From UXD to LivXD: Living eXperience Design. Hoboken: John Wiley \& Sons.

Network, G. N. (2017). Stunning Sidewalk Chalk Festival is Funding Arts in the Schools. Retrieved from goodnewsnetwork.org: https://www.goodnewsnetwork.org/streetpainting-i-madonnari-2017/

PARSONS, C. (2011, 11 14). MailOnline - news, sport, celebrity, science and health stories. Retrieved from https://www.dailymail.co.uk/news/article-2061268/Artistdraws-Chinas-terracotta-army-chalk-street-art-LEGOmen.html\%253Fito\%253Dfeeds-newsxml

Schwarzenbach, J. a. (2015). Transatlantic Reflections on the Practice-Based PhD in Fine Art. Abingdon: Routledge.

SEJACKSON907. (2017, 7 30). Perspective in 3D Art (Post Modern Blog). Retrieved from https://sejackson907.wordpress.com/2015/07/30/perspective-in-3d-art-postmodern-blog/

Sherman, W. R. (2018). Understanding Virtual Reality: Interface, Application, and Design- The Morgan Kaufmann Series in Computer Graphics. Massachusetts: Morgan Kaufmann.

Smith, C. Y. (2013). Street Art: An Analysis under U.S. Intellectual Property Law and Intellectual Property's Negative Space Theory. DePaul J. Art \& Intell. Prop., 24(1), 259-272.

Staff, S. I. (2011). Curioddities- Ripley's believe it or not! York New: Scholastic Inc. Wenner, K. (2020). Kurt Wenner Master Artist. Retrieved from https://kurtwenner.com Wenner, K. a. (2011). Asphalt Renaissance: The Pavement Art and 3-D Illusions of Kurt Wenner. USA: Sterling Signature.

M. ALSAGGAR, M. AL-ATOUM, THE ARTISTIC SOCIAL AND ENVIRONMENTAL DIMENSIONS OF 3D STREET PAVEMENT ART 215 


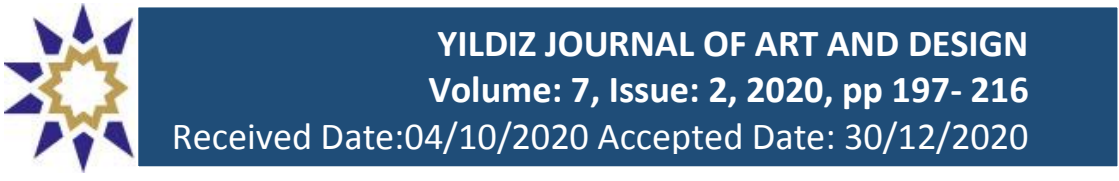

\section{Figure References}

Fig 1. Woman street painter in London, c1900; from NYPL Digital Collections: https://www.pinterest.com/pin/163114817731446108/

Fig 2. Work name: Greenpeace - Million Signatures. Workplace : Brussels, Belgium. Production date: 2010. Workload: a 4,100 square foot. http://kurtwenner.com/galleries/pavement/pavement_1/pages/StreetPaintingGallery1.003. htm

Fig 3. name: The 'make Poverty History' Workplace. Edinburgh Production date. 2005. http://www.abc-people.com/illusion/julian_beever-10.htm

Fig 4. name: Lava BurstLa. Workplace. Geldern Germany. Production Date. 2008. https://id.pinterest.com/ginihapsari/edgar-mueller/

Fig 5. The name of Artwork. 3D Lego terracotta army. Workplace. Chalk festival Sarasota, Florida. Production Date 2011. https://www.dailymail.co.uk/news/article2061268/Artist-draws-Chinas-terracotta-army-chalk-street-art-LEGO-

men.html\%253Fito\%253Dfeeds-newsxml

Fig 6. Real life: The real version of the Terracotta Army was first discovered in 1974 and it totals thousands of soldiers made for China's first emperor. https://www.dailymail.co.uk/news/article-2061268/Artist-draws-Chinas-terracotta-armychalk-street-art-LEGO-men.html\%253Fito\%253Dfeeds-newsxml

Fig 7. Artwork name 3-D STREET ART Dvưr Králové Waterfall. Workplace Czech the zoo of Dvur Kralove. Production Date 2013. Acrylics on asphalt - 25 x 6 meters. https://3d-street-art.com/03-dvur-kralove-zoo-street-art.php

M. ALSAGGAR, M. AL-ATOUM, THE ARTISTIC SOCIAL AND ENVIRONMENTAL DIMENSIONS OF 3D STREET PAVEMENT ART 216 